\title{
Glycated albumin suppresses glucose-induced insulin secretion by impairing glucose metabolism in rat pancreatic $\beta$-cells
}

Takayuki Shiraki ${ }^{1}$, Yoshikazu Miura ${ }^{2}$, Tokihiko Sawada ${ }^{*}$, Toshie Okada' ${ }^{1}$ Yuhki Sakuraoka ${ }^{1}$, Takashi Muto ${ }^{2}$ and Keiichi Kubota ${ }^{1}$

\begin{abstract}
Background: Glycated albumin (GA) is an Amadori product used as a marker of hyperglycemia. In this study, we investigated the effect of GA on insulin secretion from pancreatic $\beta$ cells.

Methods: Islets were collected from male Wistar rats by collagenase digestion. Insulin secretion in the presence of non-glycated human albumin (HA) and GA was measured under three different glucose concentrations, 3 mM (G3), $7 \mathrm{mM}(\mathrm{G} 7)$, and $15 \mathrm{mM}$ (G15), with various stimulators. Insulin secretion was measured with antagonists of inducible nitric oxide synthetase (iNOS), and the expression of iNOS-mRNA was investigated by real-time PCR.

Results: Insulin secretion in the presence of HA and GA was $20.9 \pm 3.9$ and $21.6 \pm 5.5 \mu \mathrm{U} / 3$ islets/h for $\mathrm{G} 3(P=$ 0.920 ), and $154 \pm 9.3$ and $126.1 \pm 7.3 \mu \mathrm{U} / 3$ islets/h $(P=0.046)$, for $G 15$, respectively. High extracellular potassium and $10 \mathrm{mM}$ tolbutamide abrogated the inhibition of insulin secretion by GA. Glyceraldehyde, dihydroxyacetone, methylpyruvate, GLP-1, and forskolin, an activator of adenylate cyclase, did not abrogate the inhibition. Real-time PCR showed that GA did not induce iNOS-mRNA expression. Furthermore, an inhibitor of nitric oxide synthetase, aminoguanidine, and NG-nitro-L-arginine methyl ester did not abrogate the inhibition of insulin secretion.
\end{abstract}

Conclusion: GA suppresses glucose-induced insulin secretion from rat pancreatic $\beta$-cells through impairment of intracellular glucose metabolism.

\section{Background}

It has been suggested that glycated albumin (GA) is associated with the risk of complications in diabetic patients, and is used as a marker of hyperglycemia [1]. GA is an Amadori product formed non-enzymatically through the condensation reaction of glucose with reactive proteins under conditions of hyperglycemia $[2,3]$. Amadori products undergo further irreversible reactions to yield advanced glycation end-products (AGEs) [4,5]. Thus, Amadori products are formed through a reversible process that depends on the level of glycemia, whereas AGEs are produced irreversibly and are strong inducers of inflammation [6].

\footnotetext{
* Correspondence: tsawada@dokkyomed.ac.jp

'Second Department of Surgery, Dokkyo Medical University, School of Medicine, Kitakobayashi 880, Mibu, Shimotsuga, Tochigi 321-0293, Japan Full list of author information is available at the end of the article
}

Previous studies have shown that GA itself has biological effects. Cassese et al. reported that GA induced insulin resistance in skeletal muscle cells by activating protein kinase $C \alpha$ and Src [7]. Other studies have reported that GA induces the expression of proinflammatory molecules such as monocyte chemoattractant peptide (MCP-1) and interleukin-6 [8], and genes associated with fibrosis and neovascularization [9].

In general, Amadori products/AGEs trigger signaling cascades that produce oxygen free radicals, thus exposing cells to oxidative stress $[10,11]$. Although one previous study has indicated that glucose-derived AGEs inhibit insulin secretion from pancreatic $\beta$ cells by increasing the transcription of inducible nitric oxide synthetase (iNOS) and nitric oxide [12], no investigations have addressed the effect of GA on insulin secretion from pancreatic $\beta$-cells. AGEs bind to a specific cell surface receptor, the receptor of AGE (RAGE), and

C Biomed Central

(c) 2011 Shiraki et al; licensee BioMed Central Ltd. This is an Open Access article distributed under the terms of the Creative Commons Attribution License (http://creativecommons.org/licenses/by/2.0), which permits unrestricted use, distribution, and reproduction in any medium, provided the original work is properly cited. 
exert their biological effects [13]. Because it is uncertain whether GA binds to RAGE [14], the downstream mechanism of action of GA still remains unclear. In the present study, we investigated the effect of GA on insulin secretion from pancreatic $\beta$ cells and found that GA inhibits $\mathrm{K}_{\mathrm{ATP}}$-channel-dependent insulin secretion.

\section{Methods}

The present study was approved by the ethics committee of the Laboratory Animal Research Center at Dokkyo Medical University.

\section{Agents}

GA, human non-glycated albumin (HA), $\alpha$-ketoisocapronic acid $(\alpha-\mathrm{KIC})$, and 1,3-dihydroxyacetone dimer (DHA) were purchased from Sigma-Aldrich (St. Louis, $\mathrm{MO})$, collagenase, D-glyceraldehyde (glyceraldehyde), and methylpyruvate from Wako Pure Chemical Industries Ltd. (Osaka, Japan), Ficoll 400 from Pharmacia Fine Chemicals (Uppsala, Sweden), Conray 400 (sodium iotalamate) from Daiichi Pharmaceutical (Tokyo, Japan), Dulbecco's modified Eagle medium (DMEM) from Nissui Pharmaceutical Company Ltd. (Tokyo, Japan), glucagon-like peptide-1 (GLP-1) from Peptide Institute (Osaka, Japan), forskolin and aminoguanidine (AG) from Sigma Chemical Co. (St. Louis, MO), NG-nitro-L-arginine methyl ester (L-NAME) from Dojindo Molecular Technologies, Inc. (Kumamoto, Japan), and disperse from Godo-Shusei Co. (Chiba, Japan). Anti-human GA neutralizing antibody, A717, was purchased from Exocell (Philadelphia, PA).

\section{Animals and procedures}

Male Wistar rats, 8-12 weeks after birth, were obtained from Japan SLC, Inc. (Shizuoka, Japan) and housed under semi-SPF conditions. The rats were anesthetized by intraperitoneal injection of pentobarbital sodium at $50 \mathrm{mg} / \mathrm{kg}$ body weight, and their pancreatic islets were removed and subjected to collagenase digestion [15]. The islets were then separated by Ficoll-Conray gradient centrifugation [16], and individually isolated by stereoscopic microarray in DMEM containing 2\% heat-inactivated fetal calf serum (FCS).

\section{Insulin release from pancreatic islets}

The pancreatic islets were cultured overnight at $37^{\circ} \mathrm{C}$ in RMPI containing 10\% FCS and $5.5 \mathrm{mM}$ glucose, and preincubated for 90 min in HEPES-buffered solution containing $5.5 \mathrm{mM}$ glucose at $37^{\circ} \mathrm{C}$ in $5 \% \mathrm{CO}_{2}-95 \% \mathrm{O}_{2}$. Three islets were then picked up and incubated for $60 \mathrm{~min}$ at $37^{\circ} \mathrm{C}$ in $1 \mathrm{~mL}$ of bicarbonate buffer ( $\mathrm{pH} 7.4$ ) under three different glucose concentrations, $54 \mathrm{mg} / \mathrm{dL}$ (3 mM: G3), $126 \mathrm{mg} / \mathrm{dL}$ (7 mM: G7), and $170 \mathrm{mg} / \mathrm{dL}$ (15 mM: G15), with various agents.
According to the manufacturer, GA was produced using a method described elsewhere [17]. The physiological characteristics of the GA we used in the present study have been described previously $[7,18]$; it contained $195 \mathrm{ng}$ CML (/mg protein), $94.9 \pm 3.2$ Lys modification (\%), $91.6 \pm 1.5$ Arg modification (\%), undetectable fluorescent AGE, undetectable IGF-1, and undetectable LPS. As the concentrations of the other elements were very low, we considered that the results we obtained were attributable to the biological effect of GA. In preliminary experiments, we titrated GA and HA at concentrations of $0.1,0.5,1.0$, and $5.0 \mathrm{mg} / \mathrm{mL}$ and found that $\mathrm{GA}$ at the lowest concentration, $0.1 \mathrm{mg} / \mathrm{mL}$, inhibited insulin release to a degree similar to that at higher concentrations. Also, GA has been used at $0.1 \mathrm{mg} / \mathrm{mL}$ in two previous studies $[7,18]$. Anti-human GA neutralizing antibody, A717, was added at concentrations of 1.25 and $5.0 \mu \mathrm{g} / \mathrm{mL}$. The concentrations of other agents used in the present study were: Tolb $100 \mu \mathrm{M}$, glyceraldehyde $10 \mathrm{mM}$, DHA $10 \mathrm{mM}, \alpha$-KIC $10 \mathrm{mM}$, methylpyruvate $10 \mathrm{mM}$, GLP-1 $10 \mathrm{nM}$, forskolin $10 \mu \mathrm{M}$, L-NAME $1 \mathrm{mM}$, and AG $2 \mathrm{mM}$.

A portion of the medium was withdrawn from the incubation and appropriately diluted for the insulin assay. Insulin was measured using a double-antibody RIA kit (Eiken Chemical, Tokyo, Japan) [19].

\section{Measurement of intracellular free calcium in islet $\beta$-cells}

Intracellular free calcium concentration $\left(\left[\mathrm{Ca}^{2+}\right]_{\mathrm{i}}\right)$ was measured using a modification of the method of Gilon and Henquin [20], and Miura and colleagues [21]. The overnight-cultured islet cells were loaded with fura- 2 for 45-60 min at $37^{\circ} \mathrm{C}$ in HEPES-buffered medium containing $120 \mathrm{mM} \mathrm{NaCl}, 4.8 \mathrm{mM} \mathrm{KCl}, 2.5 \mathrm{mM} \mathrm{CaCl}_{2}$, $1.2 \mathrm{mM} \mathrm{MgCl} 2,24 \mathrm{mM} \mathrm{NaHCO}_{3}$, and $10 \mathrm{mM}$ HEPES (pH 7.4), containing $1 \mu \mathrm{M}$ fura 2 -AM and $5.5 \mathrm{mM}$ glucose. Fura-2-loaded cells were placed in HEPES medium $\left(37^{\circ} \mathrm{C}\right)$ containing $3 \mathrm{mM}$ glucose and fixed in a hand-made chamber (fitted with a peristaltic pump for perfusion) mounted on the stage of an inverted IX 70 microscope (Olympus, Tokyo, Japan). The loaded cells were excited at $340 \mathrm{~nm}$ and $380 \mathrm{~nm}$, the fluorescence emitted at $510 \mathrm{~nm}$ was captured by an intensified charge-coupled device camera, and the images were analyzed using the QuantiCell 700 system (Applied Imaging, Sunderland, UK). The changes in $\left[\mathrm{Ca}^{2+}\right]_{\mathrm{i}}$ in single islet cells were calculated from the ratio of the fluorescence measured with excitation at $340 \mathrm{~nm}$ to that at $380 \mathrm{~nm}$ using the following equation $[22]:\left[\mathrm{Ca}^{2+}\right]_{\mathrm{i}}$ $(n M)=K_{d} \times\left(R-R_{\min }\right) /\left(R_{\max }-R\right) \times \beta$, where $K_{d}$ is the dissociation constant for fura-2 (224 nM), $R_{\max }$ and $R_{\min }$ are the ratios of the unbound and bound forms of the fura$2-\mathrm{Ca}^{2+}$ complex, respectively, and $\beta$ is the ratio of the fluorescence of fura 2 at $380 \mathrm{~nm}$ excitation in the 
presence of minimum calcium and saturating calcium. $R_{\max }$ and $R_{\min }$ were estimated using the fluorescence intensities of fura- 2 solution $(1 \mu \mathrm{M})$ containing $10 \mathrm{mM}$ $\mathrm{CaCl}_{2}$ and $5 \mathrm{mM}$ EGTA, respectively. The fluorescent signal generated by binding of $\left[\mathrm{Ca}^{2+}\right]_{\mathrm{i}}$ to fura-2 is not influenced by changes in the $\mathrm{pH}$ of the bathing solution over the range 6.0-7.05 [19].

\section{Measurement of cAMP content}

cAMP content was measured using a modification of the method of Nelson et al. [23]. Pancreatic islets were cultured overnight at $37^{\circ} \mathrm{C}$ in RPMI with $5 \%$ FCS and preincubated for $90 \mathrm{~min}$ in HEPES-buffered solution containing $5.5 \mathrm{mM}$ glucose at $37^{\circ} \mathrm{C}$ in $5 \% \mathrm{CO}_{2}-95 \% \mathrm{O}_{2}$. Ten islets were then picked up and incubated for $30 \mathrm{~min}$ at $37^{\circ} \mathrm{C}$ in $\mathrm{KRBH}(0.4 \mathrm{~mL})$ in the presence of stimulators. The responses were stopped by addition of $0.2 \mathrm{~mL}$ of ice-cold trichloroacetic acid (TCA) to a final concentration of $6 \%$. The culture tubes were shaken, left at room temperature for $15 \mathrm{~min}$, and centrifuged at $7800 \times g$ for $10 \mathrm{~min}$. The supernatants were thoroughly mixed with $1.5 \mathrm{~mL}$ of diethyl ether, and the ether phase containing TCA was discarded. This step was repeated three times to ensure complete elimination of the TCA. The extracts and cAMP standards were evaporated, treated with $400 \mu \mathrm{L} \mathrm{KRBH}$, and assayed for cAMP using a RIA kit from Yamasa Shoyu (Choshi, Japan) in which the samples and standards are succinylated.

\section{Real-time PCR}

Total RNA was isolated from islets using a Total RNA Isolation kit (Macherey-Nagel, Düren, Germany). Reverse transcription reactions were performed using a Rever Tra Ace $\alpha$-First Strand cDNA Synthesis Kit (TOYOBO, Osaka, Japan). Briefly, $1 \mu \mathrm{g}$ of total RNA, oligo dT-primer, and dNTPs were incubated at $65^{\circ} \mathrm{C}$ for $5 \mathrm{~min}$, then $10 \mu \mathrm{L}$ of cDNA synthesis mixture was added and the mixture was incubated at $50^{\circ} \mathrm{C}$ for $50 \mathrm{~min}$. The reaction was terminated by adding $1 \mu \mathrm{L}$ of $\mathrm{RNaseH}$ and incubating the mixture at $37^{\circ} \mathrm{C}$ for $20 \mathrm{~min}$.

The sequences of the primers were as follows: $\beta$-actin: sense-primer 5'-agccatgtacgtagccatcc-3', anti-sense 5'ctctcagctgtggtggtgaa-3'; iNOS: sense-primer 5'-caccttggagttcacccagt-3', anti-sense 5'-accactcgtacttgggatgc-3'.

Real-time PCR was performed using an ABI Prism 7700 sequence detector (Applied Biosystems, Warrington, UK). The PCR reaction was carried out in a final volume of $2 \mu \mathrm{L}$ cDNA, $12.5 \mu \mathrm{L} 2 \times$ SYBR Green (Applied Biosystems), $0.5 \mu \mathrm{L}$ of $25 \mathrm{nM}$ sense and antisense primers, and $\mathrm{H}_{2} \mathrm{O}$ up to $25 \mu \mathrm{L}$. The PCR conditions consisted of 40 cycles at $95^{\circ} \mathrm{C}$ for $30 \mathrm{~s}$ and $60^{\circ} \mathrm{C}$ for $30 \mathrm{~s}$. Samples were assayed in triplicate. Means and standard deviations were calculated from the data obtained. For each sample, at least three assays were performed. The $t$ value was calculated from the mean of three different assays. The level of expression was calculated using the formula: Relative expression ( $\mathrm{t}$-value) $=$ (Copy number of target molecule/Copy number of $\beta$ actin) $\times 1000[23]$.

\section{Western blotting}

Anti-iNOS and anti- $\beta$-actin antibodies were purchased from BD Bioscience (Franklin Lakes, NJ). Islet cells prepared as described previously were lysed with $200 \mu \mathrm{l}$ of $0.5 \%(\mathrm{w} / \mathrm{v}) \mathrm{SDS}$, and centrifuged at $10000 \mathrm{rpm}$. The supernatants were adjusted to contain equal amounts of protein by dilution, using a BCA Protein Assay Kit (Pierce, Rockford, IL). Samples (20 $\mu$ g protein) were run on $12.5 \%(\mathrm{w} / \mathrm{v})$ SDS-PAGE with $10 \%$ gel and electroblotted onto PVDF membranes. The blots were blocked for $1 \mathrm{~h}$ with $5 \%(\mathrm{w} / \mathrm{v})$ non-fat milk powder and $0.1 \%(\mathrm{v} /$ v) Tween 20 in Tris- $\mathrm{NaCl}$, then exposed to the primary antibody at a 1000 -fold dilution overnight at $4^{\circ} \mathrm{C}$. After extensive washing, the blots were incubated with the secondary horseradish-peroxidase-conjugated antibody (1:2000) for $2 \mathrm{~h}$ at room temperature. Immunoreactive bands were visualized using an enhanced chemiluminescence detection system (Amersham Life Sciences, Arlington Heights, IL). The levels of protein expression were estimated quantitatively by densitometric scanning using a Molecular Imager FX (Bio-Rad Laboratories, Hercules, CA).

\section{Statistics}

Data were expressed as means \pm SEM. All statistical analyses were performed with GraphPad Prism ver 5.0 (La Jolla, CA). Data from the two groups were compared using two-sided t-test. For Figure 3, repeated measures analysis of variance was used. Differences at $P<0.05$ were considered significant.

\section{Results and Discussion}

Effect of GA on insulin secretion induced by glucose, high $\mathrm{K}^{+}$, and tolbutamide

Insulin secretion in the presence of HA and GA was 20.9 \pm 3.9 and $21.6 \pm 5.5 \mu \mathrm{U} / 3$ islets $/ \mathrm{h}(P=0.920)$ for $\mathrm{G} 3$ (Figure 1A), and $154 \pm 9.3$ and $126.1 \pm 7.3 \mu \mathrm{U} / 3$ islets $/ \mathrm{h}$ $(P=0.046)$ for $\mathrm{G} 15$, respectively (Figure $1 \mathrm{~B})$. For $\mathrm{G} 3$, in the presence of $1.25 \mu \mathrm{g} / \mathrm{mL}$ anti-human GA neutralizing antibody, A717, insulin secretion of HA and GA was 19.7 \pm 4.4 and $23.1 \pm 6.0 \mu \mathrm{U} / 3$ islets $/ \mathrm{h}(P=0.659)$, and in the presence of $5.0 \mu \mathrm{g} / \mathrm{mL} \mathrm{A717,} \mathrm{the} \mathrm{corresponding} \mathrm{values}$ were $16.8 \pm 6.6$ and $20.4 \pm 5.2 \mu \mathrm{U} / 3$ islets $/ \mathrm{h}(P=0.693)$ (Figure 1A). For G15, in the presence of $1.25 \mu \mathrm{g} / \mathrm{mL}$ A717, insulin secretion of HA and GA was $152.7 \pm 12.8$ and $150.5 \pm 6.2 \mu \mathrm{U} / 3$ islets/h $(P=0.194)$, and in the presence of $5.0 \mu \mathrm{g} / \mathrm{mL} \mathrm{A717}$, the corresponding values were $152.7 \pm 12.8$ and $155.0 \pm 12.4 \mu \mathrm{U} / 3$ islets $/ \mathrm{h}(P=0.139)$ 
(A)

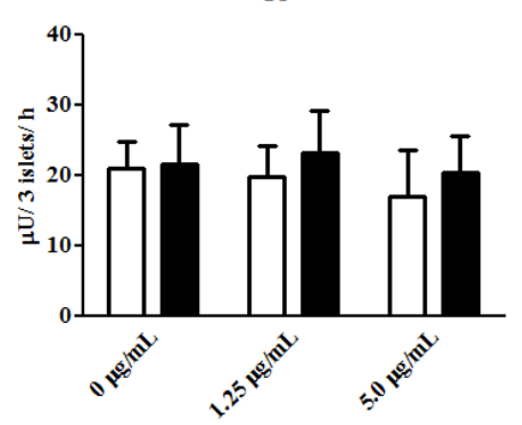

(B)

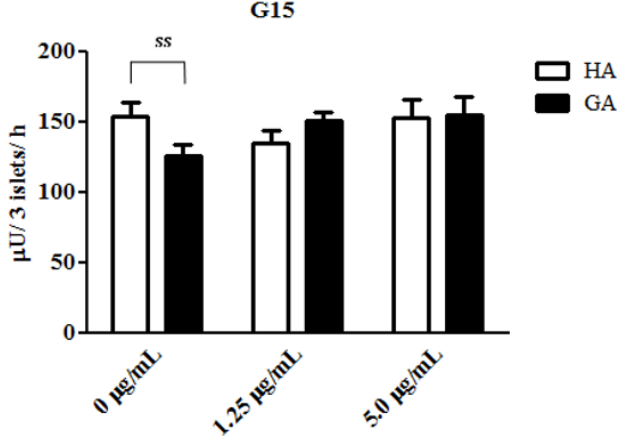

Figure 1 Effect of GA on insulin secretion. Rat islets were incubated for $24 \mathrm{~h}$ at $37^{\circ} \mathrm{C}$ with $0.1 \mathrm{mg} / \mathrm{mL} \mathrm{HA}$ (white bar) or GA (black bar) under G3 (A) or G15 (B) conditions. Labeling of the X-axis represents the dose of anti-human GA neutralizing antibody, A717. Each bar represents the mean plus SEM of 5 separate experiments, each with $n=4$. ss; statistically significant.

(Figure 1A). Thus, the anti-human GA neutralizing antibody, A717, significantly abrogated the inhibitory effect of GA on insulin secretion.

Figure 2 shows the effect of GA on the insulin secretion induced by $30 \mathrm{mM} \mathrm{K}^{+}$(K30) and Tolb. K30 depolarizes the cell membrane of islet $\beta$ cells without the need for $\mathrm{K}_{\mathrm{ATP}}$ channel closure. In the presence of K30, insulin secretion elicited by HA and GA was $116.3 \pm 6.1$ and $123.6 \pm 16.2 \mu \mathrm{U} / 3$ islets/h for $\mathrm{G} 3(P=0.686)$, and $123.3 \pm 15.7$ and $124.3 \pm 14.7 \mu \mathrm{U} / 3$ islets/h for G15, $(P$ $=0.965)$, respectively. Tolb promotes insulin secretion by binding to the regulatory sulfonylurea receptor-1 (SUR1) and inhibiting the $\mathrm{K}_{\mathrm{ATP}}$ channel current [25]. In the presence of Tolb, insulin secretion elicited by HA and GA was $42.4 \pm 3.4$ and $53.4 \pm 4.7 \mu \mathrm{U} / 3$ islets/h for

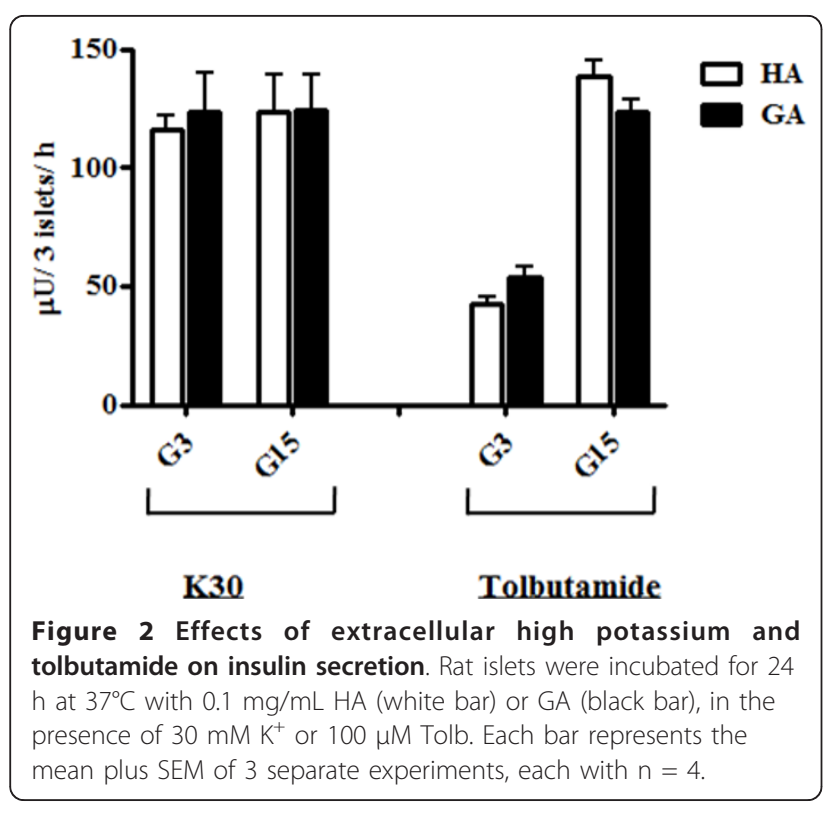

G3 $(P=0.079)$, and $138.5 \pm 6.7$ and $123.4 \pm 5.4 \mu \mathrm{U} / 3$ islets/h for $\mathrm{G} 15(P=0.536)$, respectively.

Effect of GA on intracellular $\mathrm{Ca}^{2+}$ concentration $\left[\mathrm{Ca}^{2+}\right]_{\mathrm{i}}$ Figure 3 shows the changes in $\left[\mathrm{Ca}^{2+}\right]_{\mathrm{i}}\left[\mathrm{Ca}^{2+}\right]_{\mathrm{i}}$ was measured in the presence of G3 during the first $5 \mathrm{~min}$, then in the presence of G15 for the next 10 min (Figure 3A). In the presence of $\mathrm{HA},\left[\mathrm{Ca}^{2+}\right]_{\mathrm{i}}$ reached a maximum level of $81.7 \pm 2.0 \mathrm{nM}$ at $8 \mathrm{~min}$, and remained at higher level than that in the presence of GA, which was $65.2 \pm 0.7$ $\mathrm{nM}$ at $8 \mathrm{~min}$, and thereafter remained lower than that in the presence of HA $(P=0.021)$. To investigate $\left[\mathrm{Ca}^{2+}\right]$ $i$ in the presence of a high extracellular potassium concentration or Tolb, $\left[\mathrm{Ca}^{2+}\right]_{i}$ was measured in the presence of HA or GA under the G15 condition for 5 min, followed by that in the presence of K30 (Figure 3B) or Tolb (Figure $3 \mathrm{C}$ ) for $10 \mathrm{~min} .\left[\mathrm{Ca}^{2+}\right]_{\mathrm{i}}$ increased rapidly after $5 \mathrm{~min}$ when islets were cultured in the presence of G15 and K30 $(P=0.331)$, or G15 and Tolb $(P=0.236)$.

\section{Effect of GA on insulin secretion induced by} glyceraldehyde, DHA, $\alpha$-KIC, and methylpyruvate

Glyceraldehyde and DHA enter the glycolysis pathway directly and stimulate insulin secretion [26,27]. Insulin secretion elicited by HA and GA under the G3 condition was $67.0 \pm 3.5$ and $53.6 \pm 5.3 \mu \mathrm{U} / 3$ islets $/ \mathrm{h}$ in the presence of glyceraldehyde $(P=0.044)$, and $77.2 \pm 5.2$ and $58.2 \pm 5.4 \mu \mathrm{U} / 3$ islets $/ \mathrm{h}$ in the presence of DHA $(P=0.017)$, respectively (Figure $4 \mathrm{~A})$.

$\alpha$-KIC enters mitochondrial metabolism through $\alpha$ ketoglutamate and increases insulin secretion [28]. Methylpyruvate is a membrane-permeable form of the mitochondrial fuel pyruvate, and also increases insulin secretion [29]. Under the G3 condition, insulin secretion elicited by HA and GA was $108.8 \pm 9.4$ and $107.9 \pm 7.9$ $\mu \mathrm{U} / 3$ islets $/ \mathrm{h}$ in the presence of $\alpha$-KIC $(P=0.946)$, respectively, and $96.4 \pm 6.5$ and $76.6 \pm 6.6 \mu \mathrm{U} / 3$ islets $/ \mathrm{h}$ 
(A)

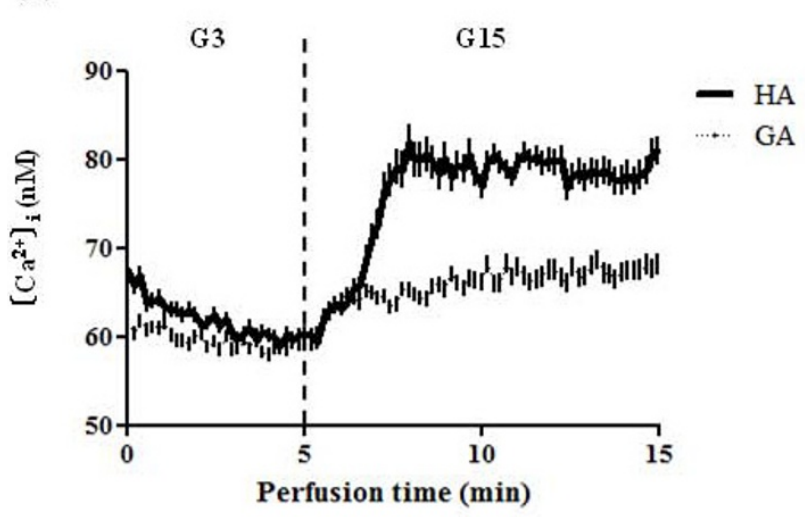

(B)

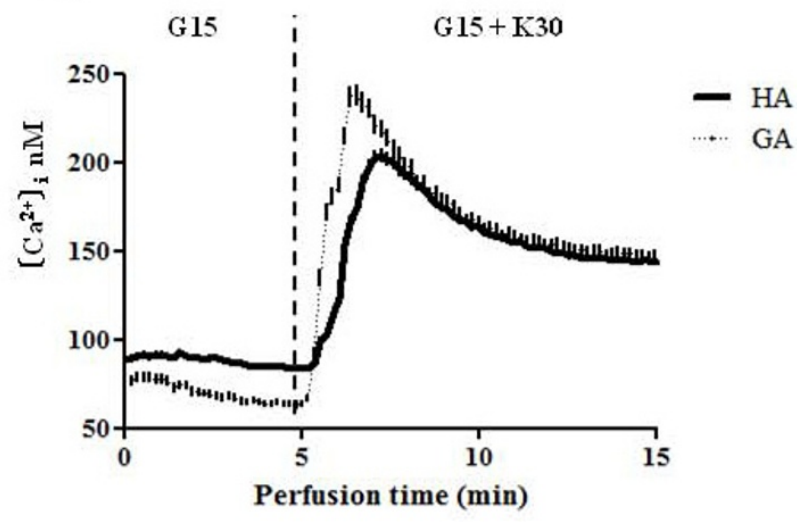

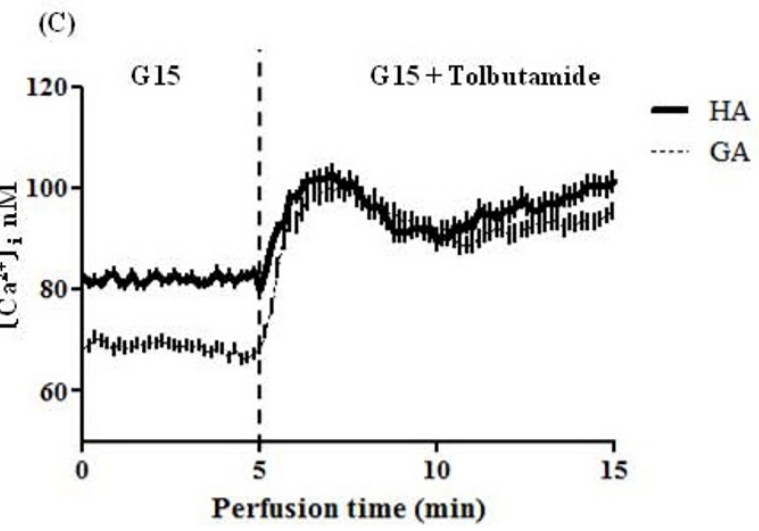

Figure 3 Changes in intracellular free calcium concentration $\left(\left[\mathrm{Ca}^{2+}\right]_{\mathrm{i}}\right)$. (A) Effect of $\mathrm{GA}$ on $\left(\left[\mathrm{Ca}^{2+}\right]_{\mathrm{i}}\right) .\left[\mathrm{Ca}^{2+}\right]_{\mathrm{i}}$ was measured under the $\mathrm{G} 3$ condition during the first $5 \mathrm{~min}$, then under the G15 condition for the next $10 \mathrm{~min}$, in the presence of $0.1 \mathrm{mg} / \mathrm{mL} \mathrm{HA}$ (thick line) or GA (thin line). Data represent the mean plus SEM of 2 separate experiments, each with $n=4-10$. (B, C) $\left[\mathrm{Ca}^{2+}\right]_{i}$ was measured in the presence of HA (thick line) or GA (thin line) under the G15 condition. Islet cells were incubated for the first $5 \mathrm{~min}$, and then in the presence of $30 \mathrm{mM} \mathrm{K}$ (B) or $100 \mu \mathrm{M}$ Tolb (C) for the next $10 \mathrm{~min}$, in the presence of $0.1 \mathrm{mg} / \mathrm{mL}$ HA (solid) or GA (dotted). Data represent the mean plus SEM of 2 separate experiments, each with $n=4-10$. ss; statistically significant.

in the presence of methylpyruvate $(P=0.047)$, respectively. Under the G15 condition, insulin secretion elicited by HA and GA was $121.4 \pm 8.0$ and $118.3 \pm 9.0$ $\mu \mathrm{U} / 3$ islets/h in the presence of $\alpha-\mathrm{KIC}(P=0.799)$, respectively, and $111.2 \pm 13.5$ and $73.5 \pm 8.2 \mu \mathrm{U} / 3$ islets/h in the presence of methylpyruvate $(P=0.031)$, respectively.

To investigate the effect of GA on insulin production, insulin concentration in $\beta$ cells was measured. The insulin content in the presence of HA and GA under the G3 condition was $1181.9 \pm 72.5$ and $1024.6 \pm 98.6 \mu$ Unit/3 islets, respectively $(P=0.222)$, and those under the G15 condition were $1143.6 \pm 49.8$ and $1040.8 \pm 65.8 \mu$ Unit/ 3 islets, respectively $(P=0.237)$.

Inhibition of insulin secretion by GA is CAMP-dependent Glucose-stimulated insulin secretion is augmented by the cAMP-dependent amplifying pathway [30]. To investigate the mechanism of inhibition of insulin secretion by GA further, insulin secretion was tested in the presence of the incretin, GLP-1, and the activator of adenylate cyclase, forskolin. Insulin secretion elicited by HA and GA under the G7 condition was $99.5 \pm 12.6$ and $61.8 \pm 9.6 \mu \mathrm{U} / 3$ islets/h $(P=0.029)$ in the presence of GLP-1, and $185.5 \pm 28.3$ and $80.1 \pm 14.3 \mu \mathrm{U} / 3$ islets/ $\mathrm{h}(P=0.005)$ in the presence of forskolin (Figure $5 \mathrm{~A})$. Figure 5B shows the cAMP content of the islet $\beta$ cells. Under the G7 condition, the cAMP contents elicited by $\mathrm{HA}$ and GA were $24.5 \pm 1.1$ and $18.1 \pm 1.4 \mathrm{pmol} / 10$ islets, respectively $(P=0.003)$, in the presence of GLP-1, and $51.4 \pm 2.7$ and $41.0 \pm 2.1 \mathrm{pmol} / 10$ islets, respectively $(P=0.018)$, in the presence of forskolin.

Inhibition of insulin secretion by GA is not iNOS-mediated Although the mechanism responsible for the suppression of insulin release by GA remains unknown, one 


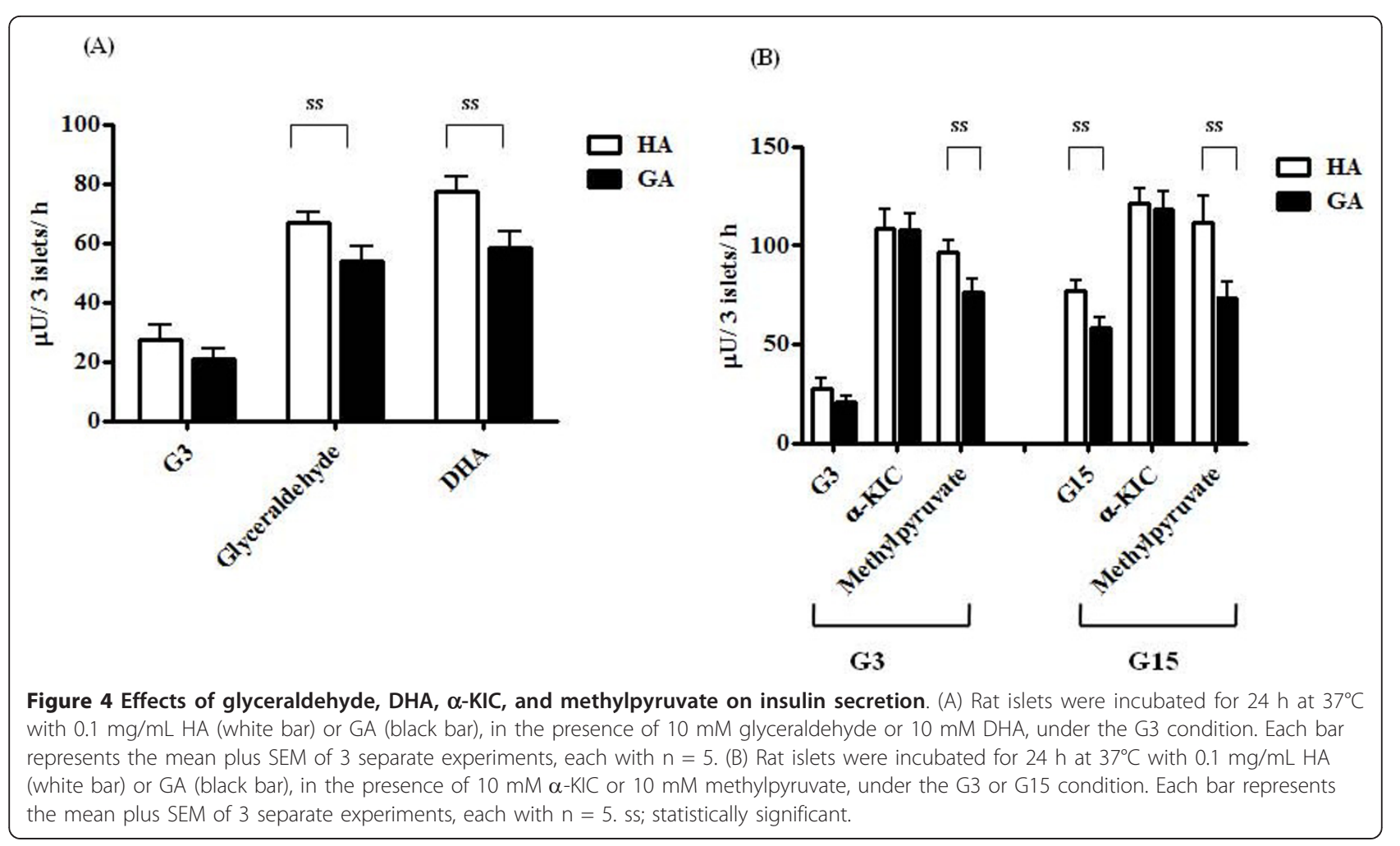

previous study has suggested that glucose-derived AGE inhibits insulin secretion by activating iNOS, resulting in the inhibition of cytochrome $c$ oxidase and ATP production [12]. Insulin secretion was therefore investigated in the presence of an inhibitor of nitric oxide synthetase, L-NAME, or a selective inhibitor of iNOS, AG [12]. Insulin secretion in the presence of $\mathrm{HA}$ and $\mathrm{GA}$ alone or with L-NAME and AG under the G3 condition was $28.2 \pm 3.3,27.6 \pm 4.1$, and $25.3 \pm 2.2 \mu \mathrm{U} / 3$ islets $/ \mathrm{h}$ for HA $(P=0.921)$, and $26.3 \pm 3.3,26.4 \pm 4.2$, and $21.1 \pm$ $2.8 \mu \mathrm{U} / 3$ islets/h for $\mathrm{GA}(P=0.895)$. The corresponding results under the G15 condition were $138.1 \pm 5.7,132.0 \pm$ 6.1 , and $135.3 \pm 8.5 \mu \mathrm{U} / 3$ islets/h for $\mathrm{HA}(P=0.724)$, and $117.5 \pm 3.8,111.3 \pm 4.4$, and $107.4 \pm 6.0 \mu \mathrm{U} / 3$ islets $/ \mathrm{h}$ for GA $(P=0.847)$. Figure $6 \mathrm{~B}$ shows the data for iNOSmRNA expression. The $t$-values of iNOS-mRNA for HA and GA were $2.2 \pm 0.7$ and $2.0 \pm 1.0$ under the G3 condition $(P=0.877), 2.4 \pm 0.8$ and $2.1 \pm 1.1$ under $\mathrm{G} 7(P<$ $0.001)$, and $2.2 \pm 0.4$ and $2.2 \pm 0.6$ under $\mathrm{G} 15(P=0.822)$, respectively. Figure $6 \mathrm{C}$ shows the results of Western blotting. The relative expression of iNOS-protein to $\beta$ actin-protein in the presence of HA and GA was 0.40 and 0.42 , respectively $(P>0.05)$.

The present study has demonstrated for the first time that glycated albumin (GA) suppresses glucose-induced insulin secretion from islet $\beta$-cells. As shown in Figure $3 \mathrm{~A}, \mathrm{GA}$ significantly decreased $\left[\mathrm{Ca}^{2+}\right]_{\mathrm{i}}$, and therefore the suppression of insulin secretion by GA may be due mainly to suppression of cytosolic $\mathrm{Ca}^{2+}$ influx in response to glucose stimulation.

Am extracellular high potassium concentration (K30) depolarizes the cell membrane without any need for the $K_{\text {ATP }}$ channel current, and activates voltage-sensitive calcium channels; the calcium influx then stimulates insulin secretion. As shown in Figure 2, K30 abrogated the inhibition of insulin secretion by GA, suggesting that GA inhibits insulin secretion upstream of voltagesensitive calcium channels. Tolb binds to SUR1 and keep the $\mathrm{K}_{\mathrm{ATP}}$ channel closed, thus inhibiting the $\mathrm{K}_{\mathrm{ATP}}$ channel influx of extracellular $\mathrm{Ca}^{+}$and inducing depolarization of the cell membrane, consequently inducing insulin secretion [25]. Tolb abrogated the inhibition of insulin secretion by GA (Figure 2), suggesting that GA did not affect the function of the $\mathrm{K}_{\mathrm{ATP}}$ channel. As both $\mathrm{K} 30$ and Tolb increased $\left[\mathrm{Ca}^{2+}\right]_{\mathrm{i}}$, (Figure $2 \mathrm{~B}$ and $2 \mathrm{C}$ ), the mechanism responsible for suppression of insulin secretion occurs upstream of the $\mathrm{K}_{\mathrm{ATP}}$ channel.

In the process of insulin secretion by $\beta$-cells, glucose is phosphorylated by glucokinase and forms glucose-6phosphate (G6P). The G6P is further metabolized via glycolysis, to generate ATP. Glyceraldehyde and DHA are potent insulin secretagogues that enter the glycolytic pathway directly and produce ATP, resulting in insulin secretion [26,27]. In the present study, glyceraldehyde and DHA did not abrogate the inhibition of insulin secretion by GA (Figure 4A). 


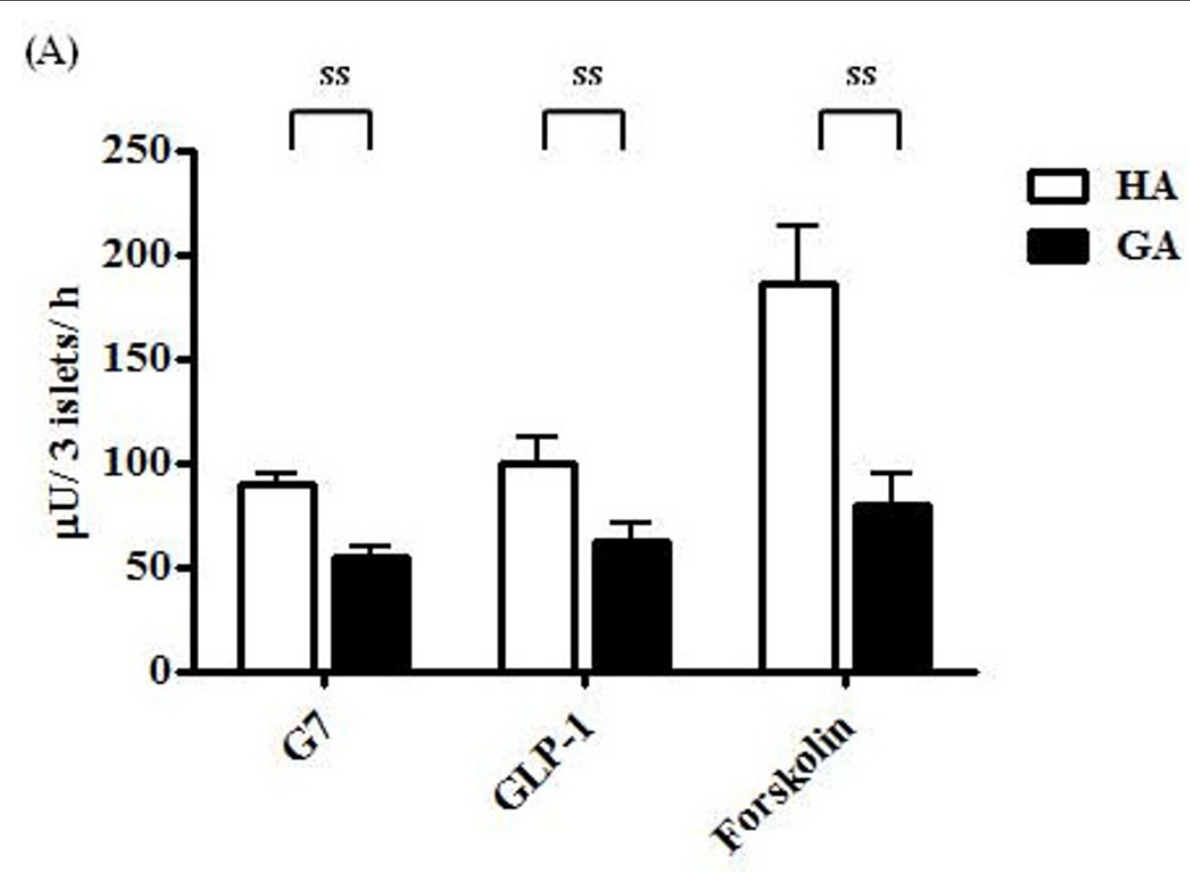

(B)
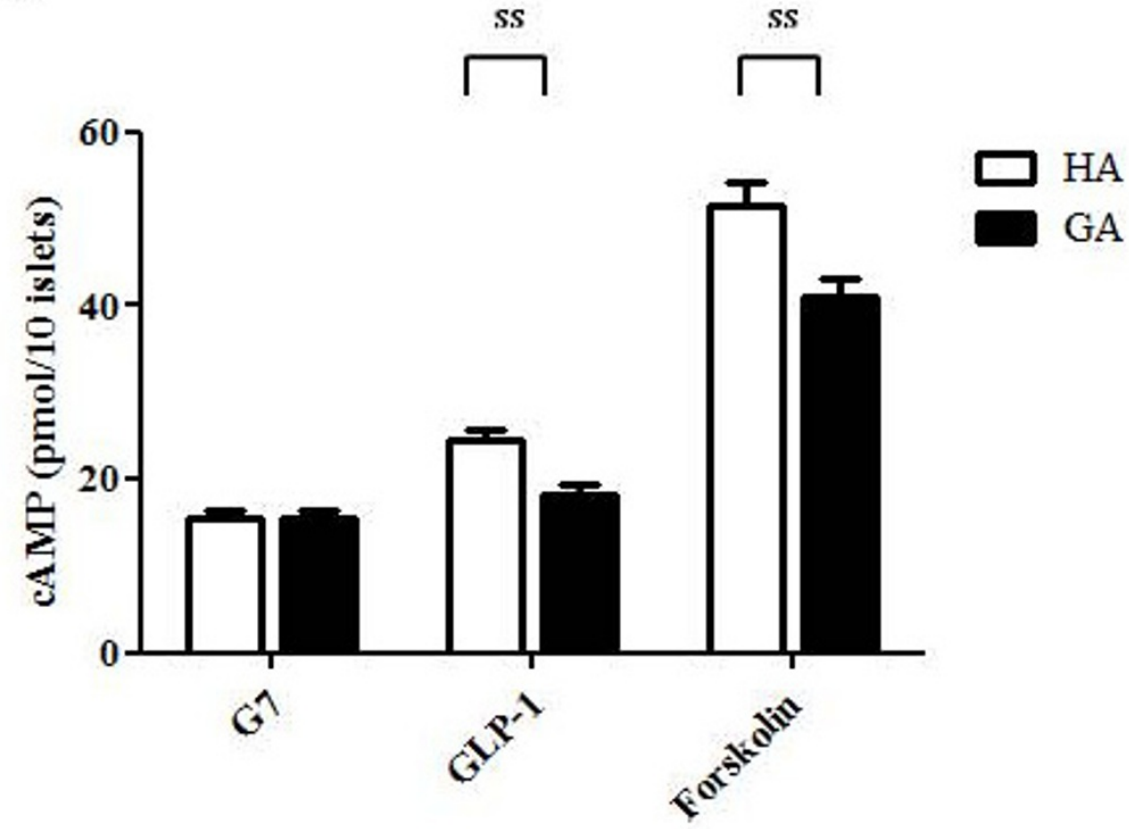

Figure 5 Effects of GLP-1 and forskolin on insulin secretion. (A) Rat islets were incubated for $24 \mathrm{~h}$ at $37^{\circ} \mathrm{C}$ with $0.1 \mathrm{mg} / \mathrm{mL} \mathrm{HA}$ (white bar) or GA (black bar), in the presence of $10 \mathrm{nM}$ GLP-1 or $10 \mu \mathrm{M}$ forskolin, under the G7 condition. Each bar represents the mean plus SEM of 3 separate experiments, each with $n=5$. (B) Dissociated islet cells were cultured overnight at $37^{\circ} \mathrm{C}$ in DMEM with $5 \% \mathrm{FCS}$. Islet cells were preincubated for $30 \mathrm{~min}$ at $37^{\circ} \mathrm{C}$ in $\mathrm{KRBH}(0.4 \mathrm{~mL})$ in the presence of GLP-1 or forskolin, under the $\mathrm{G} 7 \mathrm{condition}$. ss; statistically significant.

On the other hand, $\alpha-\mathrm{KIC}$ and methylpyruvate stimulate mitochondrial metabolism and induce insulin secretion. $\alpha$-KIC is a transamination partner, which enters mitochondrial metabolism through $\alpha$-ketoglutamate and induces mitochondrial NADPH, thus increasing insulin secretion [28]. As shown in Figure 4B, KIC restored insulin secretion from rat $\beta$-cells, and methylpyruvate [29] did not abrogate the inhibitory effect of GA. Although the discrepancy between the effects of $\alpha$-KIC and methylpyruvate is not fully understood, a previous 


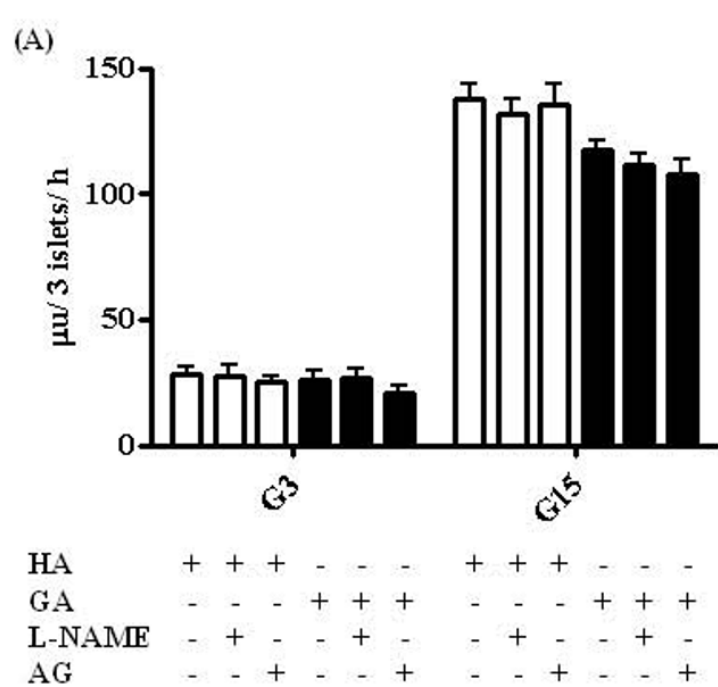

(B)

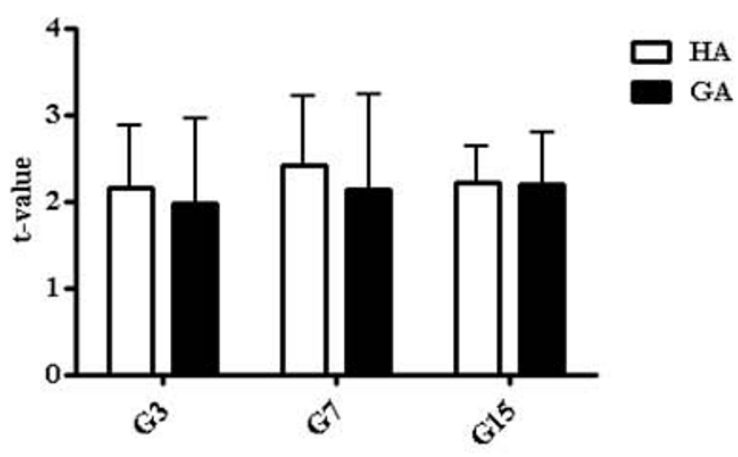

(C)

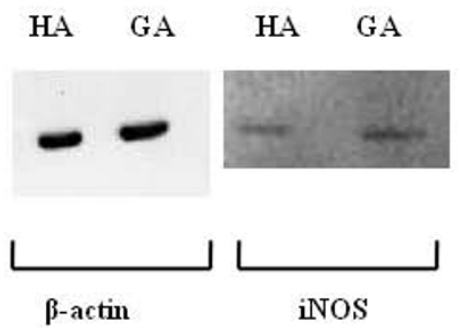

Figure 6 Inhibition of insulin secretion by GA is not iNOS-mediated. (A) Rat islets were incubated for $24 \mathrm{~h}$ at $37^{\circ} \mathrm{C}$ with $0.1 \mathrm{mg} / \mathrm{mL} \mathrm{HA}$ (white bar) or GA (black bar), in the presence of the inhibitor of nitric oxide synthetase, L-NAME, at $1 \mathrm{mM}$, or the selective inhibitor of iNOS, AG, at $2 \mathrm{mM}$, under the G3 or G15 condition. Each bar represents the mean plus SEM of 3 separate experiments, each with $n=5$. (B) Real-time PCR was performed with cDNA from RNA that had been isolated from HA- or GA-treated rat islet cells. t-value is the relative amount of iNOS-mRNA to $\beta$-actin-mRNA. (C) Rat islets were incubated for $24 \mathrm{~h}$ at $37^{\circ} \mathrm{C}$ with $0.1 \mathrm{mg} / \mathrm{mL} \mathrm{HA}$ or $\mathrm{GA}$, and the proteins isolated from islet cells were stained with anti- $\beta$-actin or anti-iNOS antibody.

study indicated that $\alpha$-KIC not only stimulates mitochondrial metabolism but also stimulates the $\mathrm{K}_{\mathrm{ATP}}$ channel directly [30]. Pyruvate is an end-product of aerobic glycolysis and transported to mitochondria after oxidization to form acetyl coenzyme A (CoA), then entering the tricarboxylic acid (TCA) cycle. In $\beta$-cells, the supply of nicotinamide adenine dinucleotide $\left(\mathrm{NAD}^{+}\right)$ from the oxidization of pyruvate is insufficient. Eto et al. reported that the NADH shuttle, including the glycerol3-phosphate shuttle and the malate-aspartate shuttle, utilizes mitochondrial electrons to reoxidize NADH, thus playing an important role in the production of ATP in $\beta$-cell mitochondria [31]. Because, in the present study, addition of methylpyruvate did not restore insulin secretion, GA appears to also impair NADH shuttle.

GLP-1 stimulates insulin secretion by increasing cAMP [34]. Forskolin is a potent activator of adenylate cyclase [35]. Activation of adenylate cyclase/cAMP leads to the activation of protein kinase $A$, which in turn increases $\mathrm{Ca}^{2+}$ influx to $\beta$-cells [36]. Because GLP-1 and forskolin did not restore insulin secretion and the
cAMP content in $\beta$-cells, it was suggested that the pathway for amplification of insulin secretion by adenylate cyclase/cAMP was also impaired by GA treatment. We also investigated the effect of acetylcholine (ACh) on the suppression of insulin secretion by GA, and found that ACh did not elicit recovery of insulin secretion (data not shown). ACh binds to the muscarinic receptor of $\beta$ cells and activates phospholipase C- $\beta$ (PLC), then stimulates release of $\mathrm{Ca}^{2+}$ from the endoplasmic reticulum [37].

Zhao et al. reported that glucose-derived AGE inhibits insulin secretion by activating iNOS, resulting in inhibition of cytochrome $c$ oxidase and ATP production [12]. Our results were contradictory to theirs; GA did not increase the expression of iNOS-mRNA (Figure 6A), and the inhibitor of nitric oxidase synthetase, L-NAME, and AG, did not restore insulin secretion. In Zhao's study, L-NAME and AG abrogated the inhibition of insulin secretion by glucose-derived AGE, although insulin secretion did not fully return to the normal level. As mentioned earlier, AGEs bind to RAGE, and 
transduce signals to downstream pathaways, including mitogen-activated protein kinases, the Janus Kinase-signal transducer and activation of transcription pathway, and phosphoinositol 3 kinase [38]. These signals result in activation of nuclear factor $\kappa \mathrm{B}(\mathrm{NF} \kappa \mathrm{B})$, and increase the expression of iNOS, C-reactive protein (CRP), transforming growth factor- $\beta$, and other molecules. Although RAGE interacts with multiple ligands, it remains unclear whether GA binds RAGE or not. GA is not an AGE, and as the mechanism involved may be different, we suggest that induction of iNOS and impairment of mitochondrial cytochrome $c$ does not play a major role in the inhibition of insulin secretion by GA.

\section{Conclusion}

GA suppresses glucose-induced insulin secretion from rat pancreatic $\beta$ cells through impairment of intracellular glucose metabolism.

\section{List of abbreviations}

GA: glycated albumin: AGEs: advanced glycation end-products

\section{Acknowledgements and funding}

The study was supported by research grants from the Japan Pancreas Research Foundation and the Japan Biomarker Society.

\section{Author details}

'Second Department of Surgery, Dokkyo Medical University, School of Medicine, Kitakobayashi 880, Mibu, Shimotsuga, Tochigi 321-0293, Japan. ${ }^{2}$ Public Health, Dokkyo Medical University, School of Medicine, Kitakobayashi 880, Mibu, Shimotsuga, Tochigi 321-0293, Japan.

\author{
Authors' contributions \\ All authors declare that the manuscipt was read and approved by all the \\ authors. \\ T.S. Reserched the data, contributed to the discussion, and wrote the \\ manuscript. \\ Y.M. Reserched the data, contributed to the discussion, and reviewed the \\ edited manuscript. \\ T.S. Reserched the data, contributed to the discussion, and wrote the \\ manuscript. \\ T.O. Researched the data. \\ YS. Researched the data. \\ T.M. Contributed to the discussion, and reviewed the edited manuscript. \\ K.K. Contributed to the discussion, and reviewed the edited manuscript.
}

\section{Declaration of competing interest}

The authors declare that they have never received reimbursements, fees, funding, or salary from any organization that may in any way gain or lose financially from the publication of this manuscript, in the past five years, currently, or in the future.

Also, the authors do not own stocks or shares in any organization that may in any way gain or lose financially from the publication of this manuscript, either currently or in the future. The authors have not applied for any patent relating to the manuscript, and have no competing financial interests.

Received: 28 December 2010 Accepted: 6 April 2011 Published: 6 April 2011

\section{References}

1. The DCCT Research Group: The effect of intensive treatment of diabetes on the development and progression of long-term complications of insulin dependent diabetes mellitus. New Eng J Med 1993, 329:977-986.
2. Bunn HF, Gabby KH, Gallop PM: The glycosylation of hemoglobin: relevance to diabetes mellitus. Science 1978, 200:21-27.

3. Cohen MP, Ziyadeh FN: Amadori glucose adducts modulate mesangial cell growth and collagen gene expression. Kidney Int 1994, 45:475-484.

4. Vlassara H, Palace MR: Diabetes and advanced glycation end products. Intern Med 2002, 251:87-101.

5. Yamagishi S, Takeuchi M, Inagaki Y, Nakamura K, Imaizumi T: Role of advanced glycation end products (AGEs) and their receptor (RAGE) in the pathogenesis of diabetic microangiopathy. Int I Clin Pharmacol Res 2003, 23:129-134.

6. Takeuchi M, Yamagishi S: Involvement of toxic AGEs (TAGE) in the pathogenesis of diabetic vascular complications and Alzheimer's Disease. J Alzheimer Dis 2009, 16:845-858.

7. Cassese A, Esposito I, Fiory F, Barbagallo AP, Paturzo F, Mirra P, Ulianich L, Giacco F, Ladicicco C, Lombardi A, Oriente F, Van Obberghen E, Beguinot F, Formisano $P$, Miele $C$ : In skeletal muscle advanced glycation endproducts (AGEs) inhibit insulin action and induce the formation of multimolecular complexes including the receptor for AGEs. J Biol Chem 2008, 52:36088-36099.

8. Hattori Y, Suzuki M, Hattori S, Kasai K: Vascular smooth muscle cell activation by glycated albumin (Amadori adducts). Hypertension 2002, 39:22-28.

9. Ziyadeh F, Han DC, Cohen JA, Guo J, Cohen MP: Glycated albumin stimulates gene expression in glomerular mesangial cells: involvement of the transforming growth factor- $\beta$ system. Kidney Int 1998, 53:631-638.

10. Schmidt AM, Yan SD, Yan SF, Stern DM: The biology of the receptor for advanced glycation end products and its ligands. Biochim Biophys Acta 2000, 1498:99-111

11. Brownlee M: Biochemistry and molecular cell biology of diabetic complications. Nature 2001, 414:813-820.

12. Zhao Z, Zhao C, Zhang XH, Zheng F, Cai W, Vlassara H, Ma ZA: Advanced glycation end products inhibit glucose-stimulated insulin secretion through nitric oxide-dependent inhibition of cytochrome $c$ oxidase and adenosine triphosphate synthesis. Endocrinology 2009, 150:2569-2576.

13. Yamagishi S, Takeuchi M, Inagaki Y, Nakamura K, Imaizumi T: Role of advanced glycation end products (AGEs) and their receptor (RAGE) in the pathogenesis of diabetic microangiopathy. Int I Clin Pharmacol Res 2003, 23:129-134.

14. Schmidt AM, Yan SD, Yan SF, Stern DM: The multiligand receptor RAGE as a progression factor amplifying immune and inflammatory responses. $J$ Clin Invest 2001, 108:959-955.

15. Koizumi M, Yada T: Sub-chronic stimulation of glucocorticoid receptor impairs and mineralocorticoid receptor protects cytosolic $\mathrm{Ca}^{2+}$ responses to glucose in pancreatic $\beta$-cells. J Endocrinol 2008, 197:221-229.

16. Okeda T, Ono J, Takaki R, Todo S: Simple method for the collection of pancreatic islets by the use of Ficoll-Conray gradient. Endocrinol Jpn 1979, 26:495-499.

17. Baynes JW, Thorpe SR, Murtiashaw MH: From Nonenzymatic glucosylation of lysine residues in albumin. In Methods in Enzymology. Edited by: Finn Wold, Kivie Moldave. Orland: Academic Press; 1984:88-99.

18. Miele C, Riboulet A, Maitan MA, Oriente F, Romano C, Formisano P, Giudicelli J, Beguinot F, Van Obberghen E: Human glycated albumin affects glucose metabolism in L6 skeletal muscle cells by impairing insulin-induced insulin receptor substrate (IRS) signaling through a protein kinase Ca-mediated mechanism. J Biol Chem 2003, 278:47376-47387.

19. Morgen CR, Lazarow A: Immunoassay of insulin. Two-antibody system, plasma insulin level of normal, subdiabetic, and diabetic rats. Diabetes 1963, 12:115-126.

20. Gilon P, Henquin JC: Activation of muscarinic receptors increases the concentration of free $\mathrm{Na}+$ in mouse pancreatic $\beta$ cells. FEBS Lett 1993, 315:353-356.

21. Miura Y, Matsui H: Glucagon-like peptide-1 induces a cAMP-dependent increase of $\left[\mathrm{Na}^{+}\right]_{\mathrm{i}}$ associated with insulin secretion in pancreatic $\beta$-cells. Am J Physiol Endocrinol Metab 2003, 285:E1001-E1009.

22. Grynkiewiez G, Poenie M, Tsien RY: A new generation of $\mathrm{Ca}^{2+}$ indicators with greatly improved fluorescence properties. J Biol Chem 1985, 260:3440-3450. 
23. Nelson TY, Gaines KI, Rajan AS, Berg M, Boyd AE III: Increased cytosolic calcium: a signal for sulfonylurea-stimulated insulin release from $\beta$ cells. J Biol Chem 1987, 262:2608-2612.

24. Okada T, Sawada T, Kubota K: Deferoxamine enhances anti-proliferative effect of interferon- $\gamma$ against hepatocellular carcinoma cells. Cancer Lett 2007, 248:24-31.

25. Ashcroft AM, Aschcroft SJH: The sulfonylurea receptor. Biochim Biophys Acta 1992, 1175:45-59.

26. Taniguchi S, Okinaka M, Tanigawa K, Miwa I: Difference in mechanism between glyceraldehyde- and glucose-induced insulin secretion from isolated rat pancreatic islets. J Biochem 2000, 127:289-295.

27. Meglasson MD, Matschinsky FM: Pancreatic islet glucose metabolism and regulation of insulin secretion. Diabetes Metab Rev 1986, 2:163-214.

28. Gao Z, Young RA, Li G, Najafi H, Buettger C, Sukumvanich SS, Wong RK, Wolf BA, Matschinsky FM: Distinguishing features of leucine and aketoisocaproate sensing in pancreatic $\beta$-cells. Endocrinology 2003, 144:1949-1957.

29. Jijakli H, Nadi AB, Cook L, Best L, Sener A, Malaisse WJ: Insulinotropic action of methyl pyruvate: enzyme and metabolic aspects. Arch Biochem Biophys 1996, 335:245-257.

30. Heissig H, Urban KA, Hastedt K, Zünkler BJ, Panten U: Mechanism of the insulin-releasing action of a-ketoisocaproate and related a-keto acid anions. Mol Pharmacol 2005, 68:1097-1105.

31. Eto $K$, Tsubamoto $Y$, Terauchi $Y$, Sugiyama T, Kishimoto T, Takahashi N, Yamauchi N, Kubota N, Murayama S, Aizawa T, Akanuma Y, Aizawa S, Kasai $\mathrm{H}$, Yazaki Y, Kaowaki T: Role of NADH shuttle system in glucoseinduced activation of mitochondrial metabolism and insulin secretion. Science 1999, 283:981-985.

32. Sakuma I, Stuehr DJ, Gross SS, Nathan C, Levi R: Identification of arginine as a precursor of endothelium-derived relaxing factor. Proc Natl Acad SCi USA 1988, 85:8644-8667.

33. Corbett JA, MCDaniel MI: The use of aminoguanidine, a selective iNOS inhibitor, to evaluate the role of nitric oxide in the development of autoimmune diabetes. Methods 1996, 10:21-30.

34. Nathan DM, Schreiber E, Fogel H, Mojsov S, Habener JF: Insulinotropic action of glucagon-like peptide-1-(7-37) in diabetic and nondiabetic subjects. Diabetes Care 1992, 15:270-276.

35. Henquin JC, Meissner HP: The ionic, electrical, and secretory effects of endogenous cyclic adenosine monophosphate in mouse pancreatic $B$ cells: studies with forskolin. Endocrinology 1984, 115:1125-1134.

36. Malaisse WJ, Malaisse-Lagae F: The role of cyclic AMP in insulin release. Experientia 1984, 40:1068-1075.

37. Gilon P, Nenquin M, Henquin JC: Muscarinic stimulation exerts both stimulatory and inhibitory effects on the concentration of cytoplasmic $\mathrm{Ca}^{2+}$ in the electrically excitable pancreatic $\beta$-cell. Biochem J 1995, 311:259-267.

38. Yan SF, Ramasamy R, Schmidt AM: Mechanism of disease: advanced glycation end-products and their receptor in inflammation and diabetes complications. Nature Clin Pract Endocrinol Metab 2008, 4:285-293.

doi:10.1186/1743-7075-8-20

Cite this article as: Shiraki et al:: Glycated albumin suppresses glucoseinduced insulin secretion by impairing glucose metabolism in rat pancreatic $\beta$-cells. Nutrition \& Metabolism 2011 8:20.

\section{Submit your next manuscript to BioMed Central and take full advantage of:}

- Convenient online submission

- Thorough peer review

- No space constraints or color figure charges

- Immediate publication on acceptance

- Inclusion in PubMed, CAS, Scopus and Google Scholar

- Research which is freely available for redistribution 